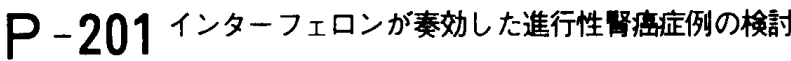

国立南和歌山病院")

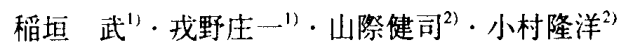

進行性腎癌において、インターフェロンを長期継続的に投与 し転移巣に著効を得た 4 症例を経験したので提示する。

症例 $1: 67$ 筬、男性。右腎癌。初診時より両側肺転移が認め られた。原発巣の摘出術を施行し、RCC, common type, clear cell subtype, pT4, N0, M1，V0と診断された。術後より天然型イ ンターフェロン $\alpha$ の連日投与を行い、投与開始後約10力月にお いて、肺転移巣の著明な縮小が認められた。症例 $2: 75$ 藏、男 性。右腎癌。初診時より肺転移および下大静脈内腫瘍塞栓が認 められ、T2, Nx, M1，V2と診断した。天然型インターフェロン $\alpha$ の連日投与を行い、投与開始後約6力月に扔いて、肺転移巣 および腫瘍塞栓の完全消失が認められた。症例 $3 ： 53$ 歳、男性。 左腎癌。根治的腎摘除術を施行し、RCC, alveolar type, clear cell subtype,pT2，N0，M0，V1a と讋断された。術後再発予防として 遺伝子組み替え型インターフェロン $\gamma$ の間久的投与を 12 力月間 行った。術後䄪20力月の時点で、肺転移および局所再発が認め られたため、遺伝子組み替え型インターフェロン $\alpha$ と $\gamma$ の同時 同量持続皮下注を5日間連続投与9日間休薬のスケジュールで開 始し、計11クールの時点で肺転移巣と局所再発腫瘍の消失が認 められた。症例 4：72瓷、男性。初診時すでに肺への多発性転 移、而側副腎転移、リンパ節転移揖よび下大静脈内腫瘍塞栓が 認められ、T3c，N2，M1，V2cと診断した。遺伝子組み替え型イ ンターフェロン $\alpha$ の投与開始後、䄪12力月において肺転移巣が 完全に消失した。

\section{P - 203インターフェロン投与による罣細胞癌のアポトー シスについての検討}

大分医科大学

平田裕二, 野村威雄, 藤田義嗣, 奈須伸吉, 三股浩光, 野村芳雄

【目的】アポト-シスは、癌、ウイルス感染、神経変性疾患な どの病態において、練胞処理機構として機能していることが 注目されている。腎細胞癌の治療としてインターフェロンが用 いられているが、アポトーシスとの関連性については不明であ る。今回、インターフェロン投与における腎細胞癌のアポトシスについて検討した。

【対象及び方法】1992年4月より1994年3月までの2年間に、腎 絊胞癌と診断され、術前にインターフェロン投与後、根治的腎 摘出術を行った24症例（男性17例、女性7例、年齢32歳〜81歳、 平均57.8歳）を対象とし、術前インターフェロン未投与にて根 治的督摘出術を行った5症例を対照とした。インターフェロン は、術前14日間連日皮下注射で投与し、インターフェロン $\alpha$ 投 与7症例、インターフェロン $\gamma$ 投与 17 症例であった。

アポトーシスの検出には、in situ end labelling法 (TUNEL法) を用いて、光学影微鏡にて、アポトーシス細胞/全細胞数を200 倍視野で計算し、アポトーシスの発生率とした。

【結果】術前にインターフェロンが投与された24症例で、10症 例において高率にアポトーシスを認め、術前インターフェロン 末投与の5拝例では、認められなかった。アポトーシスを䜑め た群について、病理組織型、stage、予後、等との関連ついて 検討するとともに、これらについてアポトーシスを認めなかっ た群とも比較し検討する予定である。

\section{P -202 インターフェロン(IFN)を中心とした多用併用 䔔法施行中に四原発望摘除術を契機とし転移果

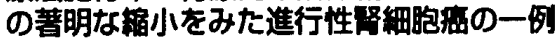

国家公務員共済組合連合会大手前病院 ${ }^{1)}$. 中野クリニック 2 近藤雅彦 ${ }^{1)}$. 芝 政宏 $^{1}$. 黑田秀也 ${ }^{11}$. 中野悦次 ${ }^{2)}$

【症例】34歳男性. 主訴：腰痛. 現病歴：1997年7月腰痛

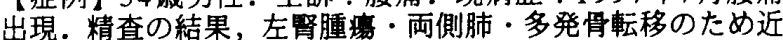

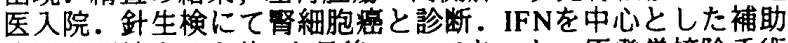
療法を開始するも約1力月後, PDであった。原発策摘除手術 を希望し，9月8日当科へ担送され，転入院となった。院 時から，春椎損傷の危険性から床上安静とした。左靔摘除術 及び春椎ハリントンロッド固定術を予定とし, 補助療法は内容 に変更を加え継続した.9月18日右下腹部知覚障害出現. 金 椎CTにて，2週間前にはみられなかった転移柴の春柱管内人 の浸潤を認めた。整形外科的には手術適応かなくなったか， 患者の強い希望により9月22日左堅摘除術のみを施行した。 術後経過順調で, 術後3日目より補助療法再開した。術後2 週後，肺転移单の縮小と春柱管内浸潤像の消失を認めた。術 後 5 週目, 肺転移单の $50 \%$ 以上の縮小と，春椎転移单の再骨 化を認め，PRと判断した。また, 腰痛, 神経症状の改善にと もないADL拡大のため,リハビリテーションを開始した。

【考察】原発巣摘除手術の是非に関しては結論はでていな い。また，IFNの有効率は，20\%前後にととまり，若干の延 命傾向があるにすきない。本症例は，補助療法に抵抗性で增 殖か早く，転移单の拡がりからも安易に堅摘除術を選択でき ない症例であつたが，結果的には，腎摘除術を契機として補 助療法が奏功した。遠隔転移を有する堅細胞聕心手術適応症 例の選択基涑は，今後の検討課題であるが，本症例のよう に，多発転移を有し，且つ增殖速度の速い症例の中にも原発 单摘除が近接効果において有奻な症例があることを念頭に膡 いて，治療法を選択する必要があると考える。

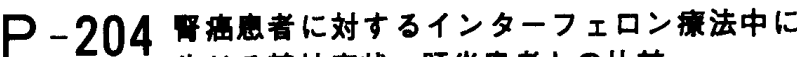 生じる粠神症状一肝炎息者との比}

昭和大学泌尿器科 ${ }^{11}$ 、同 精神科 ${ }^{2}$ 、同 第二内科 ${ }^{3}$ 坂本英雄 ${ }^{1}$ 、井上克已 ${ }^{1}$ 、島田誠 ${ }^{1}$ 、吉田英機 ${ }^{\prime}$ 、大坪天 平 $^{21}$ 、宮岡等 ${ }^{2}$ 、上島国利 ${ }^{21}$ 、石井誠 ${ }^{31}$ 、三田村圭二 ${ }^{31}$

（目的）腎癌患者のインターフェロン（IFN）療法に扔いて 精神症状は重要な副作用であることを前総会で報告した。今 回、更に症例を增やし IFN 療法中に生じる精神症状を投与前 後で評価し、肝炎患者の場合と比較検討した。

（対象及び方法）1994 年から 1997 年までにIFN 療法を開 始した腎紏胞癌 31 症例を対象とした。27 例が根治的腎摘除 術後、4 例が手術適応外とされた進行癌に用いた。精神症状 は IFN 療法開始前 1 週以内、開始 2 週後、 4 週後、8 遇後、 12 週後、 24 週後に精神科医による面接で評価した。

(㰴果) 精神症状は 31 例中 15 例 $(48 \%)$ にみられた。内訳 は抑うつ状態 14 例と不眠 1 例であった。精神症状の出現し た 14 例は全例でIFNの中止 (5 例) 、滅量 $(6$ 例) 、向精神 薬の投与 (12 例) 等なんらかの処置や治療を受けていた。ま た、抑うつ状態発現の危険因子として「神経症的性格」、「IFN 療法開始前の抑うつ状態の重症度が高い」、「疾患や IFNに 対する不安が強い」、「告知に癌という言葉を使用した」が みられた。抑うつ状態の発現は 14 例中 11 例で投与 2 週以内、 13 例で 4 週以内であった。

（考察）肝炎患者の IFN 療法での検討では精神科的処置を 要した症例は $14 \%$ で、腎癌患者では $48 \%$ と高頻度であった。 両疾患とも IFNによる精神症状は投与前の精神状態が発症 に関連し、腎癌のほうが早期に発現する傾向が認められた。 